\title{
The sipunculan fauna of Svalbard
}

\author{
Monika Kędra' \& Galena V. Murina² \\ 1 Institute of Oceanology, Polish Academy of Science, Sopot, Poland \\ 2 Institute of Biology of the Southern Seas, Academy of Sciences, Sevastopol, Ukraine
}

Keywords

Sipuncula; diversity; distribution; Svalbard.

\section{Correspondence}

Monika Kȩdra, Institute of Oceanology, Polish

Academy of Science, Powstańców Warszawy

55, 81-712 Sopot, Poland. Email:

kedra@iopan.gda.pl

doi:10.1111/j.1751-8369.2007.00005.x

\begin{abstract}
This study presents the species of Sipuncula collected in the Svalbard area $\left(74-81^{\circ} \mathrm{N}\right.$ and $\left.10-35^{\circ} \mathrm{E}\right)$ in the summer seasons from 1996 until 2005 at depths ranging from 40 to $2553 \mathrm{~m}$. The faunistic analysis of the material (1056 specimens from 251 stations) resulted in a total of six species and one subspecies, belonging to two families (Golfingiidae and Phascolionidae). One species, Golfingia vulgaris, has not been reported previously from Svalbard waters, and increases the total number of Sipuncula taxa known from Svalbard to nine. Three species dominated the collected material: G. vulgaris $53.5 \%$ of all specimens found), G. margaritacea (19.3\%) and Nephasoma diaphanes diaphanes $(15.5 \%)$. The study shows that compared with other northern regions, Svalbard hosts a relatively rich sipunculan fauna, which is most similar in species composition to the sipunculan fauna found in Asian Arctic waters. An easy-touse identification key to Svalbard Sipuncula species is given to aid field researchers in the identification of this often overlooked taxon.
\end{abstract}

Sipuncula is a phylum of exclusively marine worms. According to recent revisions, it consists of two classes, six families, 17 genera and about 150 species and subspecies (Cutler 1994). Sipunculans inhibit most marine habitats from intertidal zones to abyssal depths (Cutler 1994). Sipuncula are predominantly tropical and subtropical worms (75\% of the species). Boreal species account for $19 \%$ of the species, and $3 \%$ are bipolar and cosmopolitan species. Another 3\% occur in Arctic, Antarctic and temperate-cold waters (Murina 1975). Sipuncula are mostly deposit feeders living in various substrata, mainly containing mud, silt and sand. Some species may seek a protective shelter in molluscan shells, polychaete tubes and foraminiferan tests (Murina 1984).

Sipuncula are very often neglected in ecological studies, although they may play a considerable role in the bioerosion of coral reefs and soft rocks (Cutler 1968; Stearley \& Ekdale 1989), as food for fish, gastropods and occasionally people (Kohn 1975), and probably as bioturbators (Murina 1984; Romero-Wetzel 1987). In Arctic fjords Sipuncula may play an important role in macrobenthic communities and are among the dominant taxa (e.g. Wȩsławski et al. 1988; Włodarska-Kowalczuk \& Pearson 2004; Włodarska-Kowalczuk et al. 2004), but usually they are identified only to the phylum level. Even though a number of publications on Sipuncula from Arctic areas have been published (Théel 1905; Wesenberg-Lund 1930, 1933, 1934, 1938, 1955; Murina 1977), almost all information on Sipuncula in Svalbard comes from studies conducted at the beginning of the last century (Théel 1905; Fischer 1895, 1914, 1922, 1929). Some remarks on Sipuncula are made in Gulliksen et al. (1999), although their work should be treated with caution as their information on Svalbard species, including Sipuncula, is mostly based on the early published sources, which may be of questionable quality. Further information on sipunculans (mainly concerning species found in Asian Arctic Shelf seas and the Barents Sea) has been published by Murina (1977).

The main aim of this article is to present a synopsis of the composition and distribution of the Sipuncula in the waters of the Svalbard archipelago based on our own samples and published data. Species composition of Sipuncula found in the Svalbard area is compared with their distribution in the North Atlantic, Arctic seas and the waters around Antarctica. An identification key of Svalbard Sipuncula species is given to aid field researchers in the identification of this often overlooked taxon. 


\section{Material and methods}

The Svalbard archipelago is located between 74 and $81^{\circ} \mathrm{N}$ and between 10 and $35^{\circ} \mathrm{E}$. It is influenced mainly by two water masses, the warm West Spitsbergen Current (temperature above $2^{\circ} \mathrm{C}$ and salinity of 35 PSU (practical salinity unit)) and the cold East Spitsbergen Current (from $-1.5^{\circ} \mathrm{C}$ to $1^{\circ} \mathrm{C}, 34-35$ PSU) (Loeng 1991; BeszczynskaMöller et al. 1997). The West Spitsbergen Current is the northernmost extension of the Norwegian Atlantic Current and keeps the area free of ice throughout most of the year. The East Spitsbergen Current carries Arctic Water between Spitsbergen and Franz Josef Land, and then southward along the eastern coast of Spitsbergen (Loeng 1991). The Svalbard coast is subjected to ice scour from drifting ice in the summer months, whereas fast ice forms in the inner fjords in winter (Wȩsławski et al. 1988; Svendsen et al. 2002).

Material was collected during cruises with the RV Oceania (1996 to 2005) and RV Polarstern (ARK XVI and ARK XIX expeditions, deep-sea samples). Samples were mostly taken in the fjords of Kongsfjorden and Hornsund but were also taken in Van Mijenfjorden and Adventfjorden. Additional samples were taken in Magdalenefjorden, Storfjorden, Erik Eriksenstretet and near Kong Karls Land (material provided by Akvaplan-niva, Polar Environmental Center, N-9296, Tromsø, Norway) (Fig. 1; Table 1).

A total of 251 stations were sampled, 450 samples were taken (Fig. 1) and 1056 specimens were identified. Most
(378 of 450) samples were taken with a van Veen grab $\left(0.1-\mathrm{m}^{2}\right.$ catch area), the remainder were taken with either dredges (74 samples) or box corers (14 samples). Material was washed on a $0.5-\mathrm{mm}$ sieve and fixed in a $4 \%$ buffered formaldehyde and sea water solution. All organisms were later sorted and Sipuncula specimens were picked. The taxonomic nomenclature is adopted from Cutler (1994). The material is deposited at the Institute of Oceanology, Polish Academy of Science, in Sopot, Poland.

Cluster analysis (using group-average linking) was performed on the presence/absence data. To perform the cluster analysis, 23 species were included in total, of which nine were reported from Antarctica only. The detailed matrix with information on species occurrence in different polar areas is presented in Fig. 2. The similarities between samples were calculated using the Bray-Curtis index. Multivariate analyses were performed with the use of the PRIMER package version 6 (Clarke $\&$ Warwick 2001).

\section{Results}

Sipuncula specimens were not very numerous and were found only at 115 of the $251(45.8 \%)$ stations. At some stations Sipuncula species represented a significant part of the benthos samples and were among the dominant species. Especially rich were samples collected at the deep

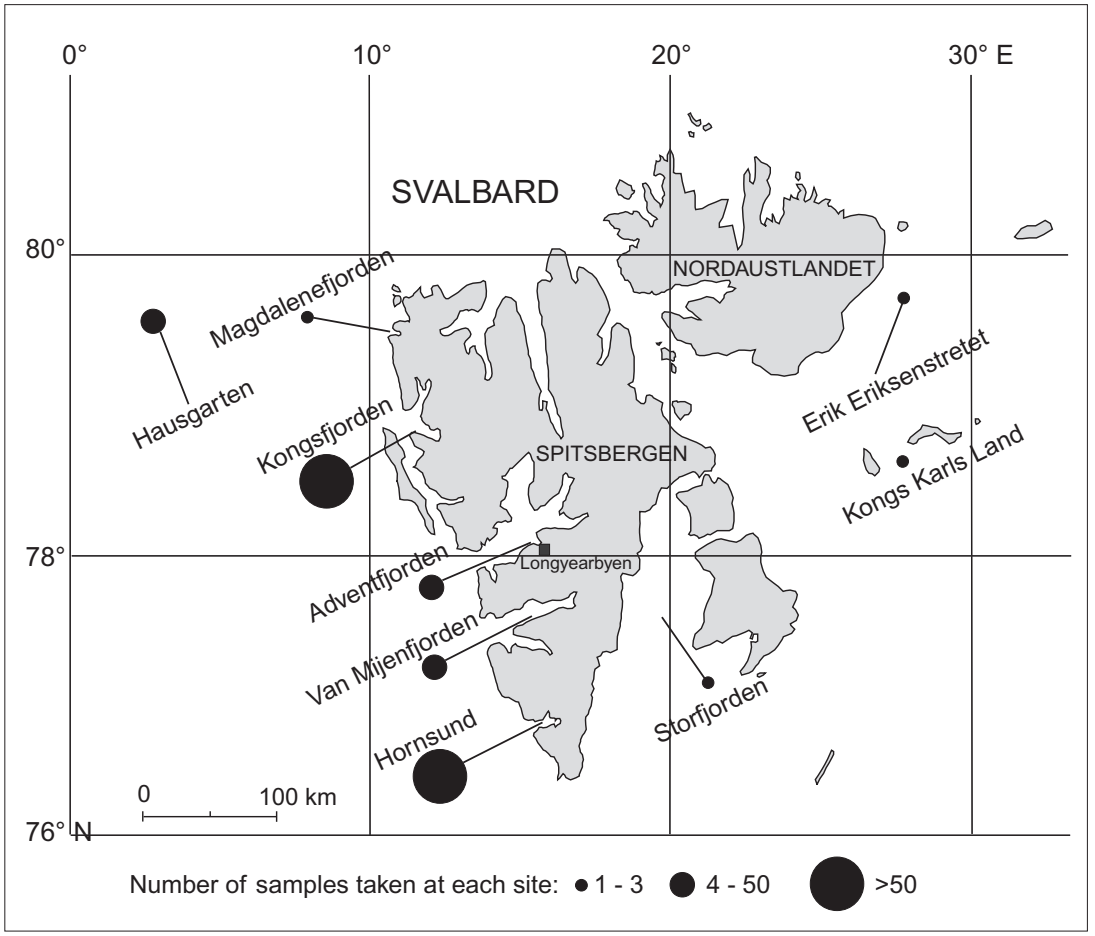

Figure 1 Location of sampling sites in the waters off Svalbard. 
Table 1 Basic information about cruises and sampling details.

\begin{tabular}{|c|c|c|c|c|c|c|}
\hline Cruise information (no. of cruises) & Area & Sampling year & Sampling gear & $\begin{array}{l}\text { Number of } \\
\text { stations }\end{array}$ & $\begin{array}{l}\text { Number of } \\
\text { samples }\end{array}$ & $\begin{array}{l}\% \text { of stations where } \\
\text { Sipuncula were found }\end{array}$ \\
\hline \multirow[t]{6}{*}{ RV Oceania (10) } & \multirow[t]{2}{*}{ Kongsfjorden } & 1996-2005 & van Veen & 70 & 155 & 52.4 \\
\hline & & 1996; 1997; 1999 & dredge & 63 & 63 & 27.7 \\
\hline & \multirow[t]{2}{*}{ Hornsund } & $2002 ; 2003 ; 2005$ & van Veen & 68 & 102 & 22.7 \\
\hline & & 2003 & dredge & 11 & 11 & 57.1 \\
\hline & Van Mijenfjorden & $2000 ; 2001$ & van Veen & 10 & 44 & 70 \\
\hline & Adventfjorden & 2004 & van Veen & 6 & 20 & 66.6 \\
\hline RV Polarstern (2) ARK XVI \& ARK XIX & Hausgarten & $2000 ; 2003$ & Box corer & 14 & 14 & 57.1 \\
\hline \multirow[t]{4}{*}{ Akvaplan-niva (1) } & Storfjorden & 1996 & van Veen & 3 & 15 & 100 \\
\hline & Kong Karls Land & & & 1 & 5 & 100 \\
\hline & Magdalenefjorden & & & 3 & 15 & 33.3 \\
\hline & Erik Eriksenstretet & & & 2 & 10 & 66.6 \\
\hline Total (13) & & & & 251 & 450 & 45.8 \\
\hline
\end{tabular}

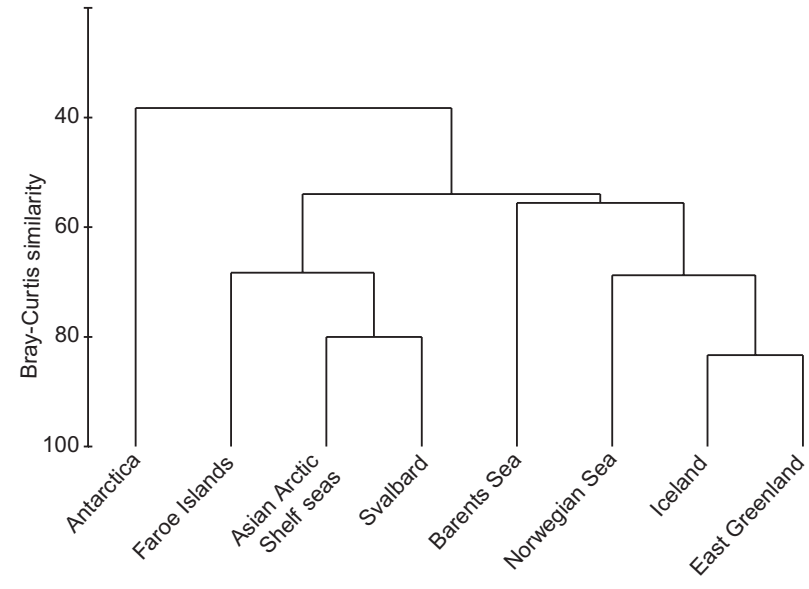

Figure 2 Dendrogram showing the faunistic resemblances in the composition of the sipunculan fauna of various northern polar and subpolar regions: Faroe Isles (Murina \& Sørensen 2004); Iceland (Wesenberg-Lund 1937b); East Greenland (Wesenberg-Lund 1937a); Norwegian Sea (Murina 1977); Barents Sea (Sirenko 2001); Asian Arctic Shelf seas (Sirenko 2001); Antarctica (Saiz-Salinas 1995; Saiz-Salinas \& Pagola-Carte 1999); and Svalbard (this study).

sea sites, at Hausgarten, (a maximum of 404 specimens per $1 \mathrm{~m}^{2}$ were found) and in Kongsfjorden (a maximum of 840 and 520 specimens per $1 \mathrm{~m}^{2}$ were found at the two sites sampled). Nevertheless, at most of the stations we found only a few specimens or a single specimen. Table 2 shows the distribution, type of substrata on which particular species were found and abundances of Sipuncula species in Svalbard waters.

Seven species have been reported from the Svalbard archipelago in the past (Table 3 ). We have recognized seven taxa: six species and one subspecies, belonging to two families (Golfingiidae and Phascolionidae), of which two have not been reported previously from the Svalbard area (Golfingia vulgaris and Nephasoma diaphanes corrugatum). In the collected material three species dominated among the Sipuncula fauna found in this study: G. vulgaris $(53.5 \%$ of all specimens found), G. margaritacea $(19.3 \%)$ and $N$. diaphanes diaphanes (15.5\%). G. elongata was the rarest species, occurring at only seven stations (nine specimens-less than $1 \%$ of all specimens found).

For each species found in our material some remarks on their distribution and biotope are provided. Table 4 contains the information on the depth distribution in the World Ocean, the North Atlantic, the Arctic and Svalbard waters (this study).

\section{Golfingia margaritacea margaritacea (Sars, 1851)}

This cold water and cosmopolitan species is widely distributed. Many reports are from cold and temperate (boreal) regions, especially in the shelf and bathyal zone. It has rarely been found in the tropical and subtropical zone. It occurs in the Atlantic, Arctic and Antarctic oceans (from $80^{\circ} \mathrm{N}$ to $78^{\circ} \mathrm{S}$ ) as well as in the Pacific ocean (above $30^{\circ} \mathrm{N}$ and $30^{\circ} \mathrm{S}$ ), but it is unknown in the Indian Ocean. It inhabits mud and sand/gravel bottoms, and red clay in the abyssal (Gibbs 2001).

\section{Golfingia vulgaris vulgaris (De Blainville, 1827)}

This cold water and cosmopolitan species is encountered extensively in the World Ocean, particularly in the northeastern Atlantic, including the waters off Greenland, Scandinavia and the British Isles, as well as in the Mediterranean and Red seas. Its absence from the western Atlantic Ocean is noteworthy. This species occurs rarely in the Arctic zone: there are some reports from the Barents, East Siberian and Chukotsk seas. It usually inhabits silt, mud, different types of sand and clay in deep waters (Saiz-Salinas \& Villafranca Urchegui 1990). 
Table 2 Distribution of Sipuncula in Svalbard waters (number of specimens found in each area) and the substrate types in which specimens were found.

\begin{tabular}{|c|c|c|c|c|c|c|c|c|c|c|}
\hline & $\mathrm{K}$ & $\mathrm{H}$ & VM & A & $\mathrm{EE}$ & S & $M$ & KK & $\mathrm{HG}$ & Total \\
\hline $\begin{array}{l}\text { Golfingia margaritacea } \\
\text { mud } \\
\text { G. vulgaris }\end{array}$ & 11 & 182 & 10 & & & 1 & & & & 204 \\
\hline $\begin{array}{l}\text { mud, sandy mud, bioturbated } \\
\text { mud, clay/mud (30-40\% clay) }\end{array}$ & 382 & 161 & 1 & 5 & 2 & 2 & 2 & 10 & & 565 \\
\hline $\begin{array}{l}\text { G. elongata } \\
\text { mud and sandy mud }\end{array}$ & 5 & 5 & & & & & & & & 10 \\
\hline $\begin{array}{l}\text { Nephasoma lilljeborgi } \\
\text { silty/sandy clay }\end{array}$ & & & & & & & & & 55 & 55 \\
\hline $\begin{array}{l}\text { N. diaphanes diaphanes } \\
\text { sandy mud, clay, mud }\end{array}$ & 43 & 3 & 1 & 2 & 2 & & & & 113 & 164 \\
\hline $\begin{array}{l}\text { N. diaphanes corrugatum } \\
\text { sandy mud, mud }\end{array}$ & 3 & 2 & & & & & & & & 5 \\
\hline $\begin{array}{l}\text { Phascolion strombus } \\
\text { sand, muds, sandy silt }\end{array}$ & 41 & 3 & & & 2 & 7 & & & & 53 \\
\hline
\end{tabular}

K, Kongsfjorden; H, Hornsund; VM, Van Mijenfjorden; A, Adventfjorden; EE, Erik Eriksenstretet; S, Storfjorden; M, Magdalenefjorden; KK, Kong Karls Land; HG, Hausgarten.

Table 3 Sipunculan species reported from the Svalbard archipelago by various sources.

\begin{tabular}{|c|c|c|c|c|c|c|c|c|}
\hline Species & Fischer 1895 & Théel 1905 & Fischer 1914 & Fischer 1922 & Fischer 1929 & Murina 1977 & $\begin{array}{l}\text { Gulliksen } \\
\text { et al. } 1999\end{array}$ & This study \\
\hline Golfingia margaritacea & & $x$ & $x$ & $x$ & $x$ & $x$ & $x$ & $x$ \\
\hline G. vulgaris & & & & & & & & $x$ \\
\hline G. elongata & & & & & & $x$ & & $x$ \\
\hline Nephasoma diaphanes diaphanes & & & & $x$ & $x$ & & $x$ & $x$ \\
\hline N. diaphanes corrugatum & & & & & & & & $x$ \\
\hline N. lilljeborgi & $x$ & $x$ & & & $x$ & & & $x$ \\
\hline N. eremita & & $x$ & & $x$ & $x$ & $x$ & $x$ & \\
\hline N. abyssorum & $x$ & & & $x$ & $x$ & $x$ & & \\
\hline Phascolion strombus & $x$ & $x$ & & $x$ & $x$ & $x$ & $x$ & $x$ \\
\hline
\end{tabular}

Table 4 Depth range (m) of Sipuncula taxa found in the World Ocean (Murina 1977; Cutler 1994; Murina, unpubl. data), North Atlantic from $60^{\circ} \mathrm{N}$ to $40^{\circ} \mathrm{N}$ (Cutler 1994; Murina 1977; Murina, unpubl. data), North Atlantic $>60^{\circ} \mathrm{N}$ (Murina 1977; Murina, unpubl. data) and in Svalbard waters (this study).

\begin{tabular}{|c|c|c|c|c|c|c|c|c|}
\hline \multirow[b]{2}{*}{ Taxon } & \multicolumn{2}{|c|}{ World Ocean } & \multicolumn{2}{|c|}{$\begin{array}{l}\text { North Atlantic } \\
60^{\circ}-40^{\circ} \mathrm{N}\end{array}$} & \multicolumn{2}{|c|}{$\begin{array}{l}\text { North Atlantic } \\
>60^{\circ} \mathrm{N}\end{array}$} & \multicolumn{2}{|c|}{ Svalbard } \\
\hline & $\min$. & Max. & $\min$. & $\max$. & $\min$. & $\max$. & $\min$. & $\max$ \\
\hline Golfingia margaritacea & 0 & 5300 & 72 & 4600 & 8 & 3230 & 67 & 290 \\
\hline G. vulgaris & 5 & 2000 & 37 & 248 & 15 & 1480 & 64 & 374 \\
\hline G. elongata & 10 & 590 & 0 & 73 & $?$ & $?$ & 79 & 162 \\
\hline Nephasoma diaphanes diaphanes & 0 & 5300 & 10 & $4800^{a}$ & 446 & 2701 & 40 & 2553 \\
\hline N. diaphanes corrugatum & 80 & 5900 & & & & & & \\
\hline N. lilljeborgi & 65 & 2734 & & & 40 & 2200 & 1912 & 2553 \\
\hline N. eremita & 0 & 3867 & & & 73 & 515 & - & - \\
\hline N. abyssorum & 95 & 5300 & & & 95 & 973 & - & - \\
\hline Phascolion strombus & 1 & 4030 & 9 & 2090 & 15 & 1890 & 79 & 390 \\
\hline
\end{tabular}




\section{Golfingia elongata (Keferstein, 1862)}

This tropical and boreal species is cosmopolitan in the Northern Hemisphere, in the north-western Atlantic (from Newfoundland to Bermuda and Cuba) and northeastern Atlantic (from Spitsbergen to the Iberian Peninsula and in the Mediterranean Sea) and in the Pacific Ocean (eastern and southern China and Vietnam). It is rare in the Arctic zone: Greenland, Spitsbergen and Iceland (Cutler 1994). It prefers the upper sublittoral (SaizSalinas \& Villafranca Urchegui 1990). It often inhabits hard ground, gravel, sand, shelf rock; less often it inhabits silt, clay and mud (Cutler 1994; Saiz-Salinas \& Villafranca Urchegui 1990).

\section{Nephasoma diaphanes diaphanes (Gerould, 1913)}

This is a cosmopolitan species with widely ranging vertical distribution. It is the most common sipunculan in deep-sea communities (Cutler \& Cutler 1987a). In Arctic waters it was reported from Spitsbergen, Novaya Zemlya and the Barents Sea. This species inhabits silt, sand and mud, and is often found in foraminiferal tests, small polychaete tubes and mollusc shells (Cutler 1994). In this study it was usually found in the shelter of foraminiferal tests.

Cutler \& Cutler (1986) regarded N. minutum (Keferstein 1862) as a hermaphrodite species confined to the north-eastern Atlantic. In contrast, $N$. diaphanes, which is morphologically and anatomically similar to N. minutum, is dioecious and cosmopolitan (Cutler \& Cutler 1986). Murina \& Sørensen (2004) considered $N$. diaphanes as a junior synonym of $N$. minutum and agreed with Gibbs' (1975) opinion: “The morphologically similar specimens now regarded as a single species have two distinct forms, a dioecious form found chiefly in deep water, and a hermaphroditic form found on the shore and in shallow water around Europe and Scandinavia". Accordingly, the name $N$. diaphanes is used in this paper.

\section{Nephasoma diaphanes corrugatum Cutler and Cutler, 1986}

This subspecies is widely distributed in the Atlantic and Pacific oceans, as well as in the Mediterranean and Red seas.

\section{Nephasoma lilljeborgi (Danielssen and Koren, 1880)}

This species is of Arctic/boreal origin. According to Cutler $\&$ Cutler (1987a) it is only known to inhabit the northern deep-sea basins in the far north-eastern Atlantic Ocean between $70^{\circ}$ and $80^{\circ} \mathrm{N}$, and might therefore be endemic to these regions (Cutler 1994). It was reported from Spitsbergen, Greenland, Baffin Bay, the Norwegian coast, the western part of Sweden, the eastern part of Iceland and the Russian seas (the Kara, Laptiv, East Siberian and Chukchi seas). It inhabits muds, clay and sandy mud.

Nephasoma diaphanes often occurred with $N$. lilljeborgi in the same samples, although $N$. diaphanes is a more eurybathic species that was found at a wider range of depths (40-2553 m).

\section{Phascolion strombus strombus (Montagu, 1804)}

This is a cosmopolitan but mainly cold water species that is widely encountered in all oceans (rare findings in the Indian Sea). It is common in Russian arctic seas. It prefers the littoral and sublittoral, penetrates in bathyal and is rare in abyssal zones. Usually it inhabits sand, mud and silt, and is often found in mollusc shells and polychaete tubes (Hylleberg 1970). In this study it was found sometimes in Gastropoda shells and Polychaeta tubes.

\section{Discussion}

The results of this study show that the Svalbard area hosts a relatively rich (for the High Arctic region) sipunculan fauna. We increased the total number of sipunculan taxa now known from the Svalbard area from seven to nine. Cluster analysis of Sipuncula assemblages from different regions showed that the Sipuncula species composition of the Svalbard region is most similar to the one from the Asian Arctic seas. The sipunculan fauna includes members of the same taxa in both areas except for G. elongata, which has not been reported from the Asian Arctic seas (Sirenko 2001). The Barents Sea (Sirenko 2001) clusters (although not very well) with the other North Atlantic areas except for the Faroe Islands. A relatively low number of sipunculan taxa (six) was reported from East Greenland (Wesenberg-Lund 1937a) and Iceland (Wesenberg-Lund 1937b). The Arctic regions are well separated from the Antarctic, where twice as many species of Sipuncula are found (Saiz-Salinas 1995; SaizSalinas \& Pagola-Carte 1999; Cutler et al. 2001) (Fig. 2).

In general, there is an increase in species richness from high to lower latitudes. This trend has been shown for many groups of marine organisms, both benthic and planktonic (Stevens 1989; Angel 1996; Ormond et al. 1997). Even though the paradigm of the latitudinal distribution of species richness is still subject to discussion (Gray 2001), Sipuncula seem to follow this rule. The phylum is undoubtedly centred in warmer waters, where the great majority $(75 \%)$ of species is found. The highest 
species diversity is found in the Indo-West Pacific and particularly in the Indo-Malayan archipelago. These regions are thus regarded as the main centre of origin and development of Sipuncula (Murina 1975). In the Atlantic Ocean the number of Sipuncula species decreases towards higher latitudes, although the decrease towards the south is not as strong as towards the north. In the North Atlantic the diversity of Sipuncula is highest off Ireland (21 species) and in the North Sea (17 species). It decreases with latitude to Svalbard (eight species) and the Asian Arctic seas (seven species). Even though more species are reported from the Antarctic area (16) (SaizSalinas 1995; Saiz-Salinas \& Pagola-Carte 1999; Cutler et al. 2001), there is a progressive loss of genera and species along a polar gradient from locations above the Antarctic Convergence to the high latitudinal Antarctic regions (Saiz-Salinas 1995). The effects of extreme cold temperatures appear to be the main structuring factor, although other, as yet unknown, factors may be of importance in determining this biodiversity gradient (Saiz-Salinas \& Pagola-Carte 1999).

The higher number of Sipuncula species in the Southern Ocean than in the Arctic may be caused by the greater age of the former region. Antarctica has been isolated for about 40 million years (Dunton 1992), whereas the Arctic Ocean has existed for only 2-3 million years (Dayton et al. 1994). The fact that the Southern Ocean covers a larger area may contribute to its greater species richness. Bouchet \& Waren (1979) supposed that in addition to the effects of age and isolation, the homogeneity and absence of geographic isolating barriers within the Arctic abyssal area could result in low species richness. The Arctic Ocean fauna, located between two major oceans, is young and of mixed origins. Repeated Pleistocene glaciations were lethal to inhabitants of the Arctic Ocean and are the reason for the youth of the fauna and its low diversity (Dunton 1992). The harshness and relative homogeneity of habitats in the Arctic are also common explanations (Clarke \& Crame 1997).

Sipunculans inhabit all of the seas of the world and are found at all latitudes. The zoogeographical range of many species is difficult to define because of their tolerance of a broad range of temperatures and depths. Moreover, many have planktonic larvae that play a very important role in determining their wide geographical distribution (Scheltema \& Hall 1975; Scheltema \& Rice 1990). Teleplanic larvae of Sipunculans are abundant across entire ocean basins (Scheltema 1975; Scheltema \& Rice 1990). Ranges appear to be determined by water temperature, bottom topography and water currents (Cutler $\&$ Cutler 1987b). The sipunculan fauna on most oceanic islands appears to include mostly species with wide geographical distributions, and very few endemic species are known
(Scheltema \& Hall 1975). However, the potential larval dispersal may be quite different from the realized larval dispersal: many marine species with teleplanic larvae may have more limited ranges than are hypothesized on the basis of their potential for larval dispersal. Furthermore, either potential or realized larval dispersal does not necessarily confer genetic homogeneity across a species with a large range (Staton \& Rice 1999). There is evidence for cryptic speciation in Apionsoma misakianum (Staton \& Rice 1999), and species delimitation may not be as clear as previously thought, especially for disjunct "populations" (Maxmen et al. 2003). However, it is unusual to find two morphologically cryptic species that are not sister species (Schulze et al. 2007). All polyphyletic species examined by Schulze et al. (2007) were geographically widespread and inhabit hard substratesmostly coral rubble-in shallow waters, and belong to genera that do not occur in polar areas.

No endemism is shown by either Antarctic or Arctic Sipuncula species (except for $N$. lilljeborgi, which might be endemic to cold deep waters). Many of the most abundant species in both areas (G. margaritacea, $N$. diaphanes and P. strombus) are cosmopolitan (Saiz-Salinas \& PagolaCarte 1999). The most numerous biogeographical group of Sipuncula species found off Svalbard are widespread in the Atlantic Ocean, occurring at a range of depths and in a wide variety of substrata. G. margaritacea and P. strombus have a very wide distribution in the Atlantic Ocean, but live at greater depths at lower latitudes (Cutler 1994). In Svalbard waters they were found only below $400 \mathrm{~m}$. One species (G. elongata) is a tropical/boreal one, but in Svalbard waters it seems to occur rarely.

The genus Nephasoma is especially richly represented in cold bathyal and abyssal waters of the northern Atlantic and Pacific (Cutler 1994). N. abyssorum has repeatedly been reported from Svalbard (Fischer 1895, 1922, 1929) but was not found in this study. It is a common bathyal and abyssal species in the north-eastern Atlantic and the Arctic Ocean. It is very likely that it is still present in the Svalbard area but has been missed in our survey because of the scarcity of deep-sea samples. The same conclusion applies to $N$. eremita. This bipolar species has previously been reported from Svalbard (Théel 1905; Fischer 1922, 1929; Gulliksen et al. 1999) but did not occur in our samples (Table 3).

It is very likely that the poor knowledge regarding the Sipuncula may lead to erroneous statements regarding the occurrence of sipunculans in Arctic regions. That was probably the reason that $G$. vulgaris has not been reported from Svalbard, although it is a widely distributed species in Greenland, Scandinavia (Théel 1905; Wesenberg-Lund 1925, 1937a; Cutler 1994) and in many Arctic seas (Sirenko 2001). 


\section{Acknowledgements}

We would like to express our deep thanks to the crew and staff of the RV Oceania and the RV Polarstern involved in the expeditions. We would like to thank Akvaplan-niva, Polar Environmental Center, N-9296, Tromsø, Norway for providing samples. Many thanks to the Naturalis National Natural History Museum, in Leiden, the Zoological Museum of the University of Copenhagen and the Museum of Natural History, in Berlin, for providing us access to their collections. Many thanks to the Zoological Museum of the University of Copenhagen, for providing us with the opportunity to take pictures and for allowing us to use their scanning electron microscope. We would like to acknowledge the financial support of the European Commission's Research Infrastructure Action via the SYNTHESYS Project.

\section{References}

Angel M.V. 1996: Oceanic biodiversity: origins and maintenance. In G. Albertelli et al. (eds.): Atti del 11 Congresso della Associazione Italiana di Oceanologia e Limnologia, Sorrento, 26-28 Ottobre 1994. (Proceedings of the 11th Congress of the Italian Association of Oceanography and Limnology, Sorrento, 26-28 October 1994.) Pp. 33-60. Genova: AIOL.

Beszczynska-Möller A., Wȩsławski J.M., Walczewski W. \& Zajączkowski M. 1997: Estimation of glacial meltwater discharge into Svalbard coastal waters. Oceanologia 39, 289-298.

Bouchet P. \& Waren A. 1979: The abyssal molluscan fauna of the Norwegian Sea and its relation to other faunas. Sarsia 64 , 211-243.

Clarke A. \& Crame J.A. 1997: Diversity, latitude and time: patterns in the shallow sea. In R.F.G. Ormong et al. (eds): Marine biodiversity. Patterns and processes. Pp. 122-147. Cambridge: Cambridge University Press.

Clarke K.R. \& Warwick R.M. 2001: Change in marine communities: an approach to statistical analysis and interpretation. 2nd edn. Plymouth: Plymouth Marine Laboratory.

Cutler E.B. 1968: A review of coral-inhabiting Sipuncula. Océanographie 3, 51-63.

Cutler E.B. 1994: The Sipuncula. Their systematics, biology, and evolution. New York: Cornell University Press.

Cutler E.B., Cean H.K. \& Saiz-Salinas J.I. 2001: Sipuncula from Antarctic waters. Proceedings of the Biological Society of Washington 114, 861-880.

Cutler E.B. \& Cutler N.J. 1986: A revision of the genus Nephasoma (Sipuncula: Golfingiidae). Proceedings of the Biological Society of Washington, 99, 547-573.

Cutler E.B. \& Cutler N.J. 1987a: Deep-water Sipuncula from the eastern Atlantic Ocean. Sarsia 72, 71-89.

Cutler E.B. \& Cutler N.J. 1987b: Revision of the genus Golfingia (Sipuncula: Golfingiidae). Proceedings of the Biological Society of Washington 100, 735-761.

Dayton P.K., Mordidia B.J. \& Bacon F. 1994: Polar marine communities. American Zoology 34, 90-99.
Dunton K. 1992: Arctic biogeography: the paradox of the marine benthic fauna and flora. Trends in Ecology and Evolution 7, 183-189.

Fischer W. 1895: Die Gephyreen des Naturhistorschen Museums zu Hamburg. (Gephyreans of the Natural History Museum in Hamburg.) Abhaltungen aus dem Gebiet der Naturwissenschaften (Hamburg) 13, 1-24.

Fischer W. 1914: Weitere Mitteilungen über die Gephyreen des Naturhistorischen (Zoologischen) Museums zu Hamburg. (Further reports on the gephyreans of the Natural History [Zoological] Museum in Hamburg.) Jahrbuch der Hamburgischen Wissenschaftlichen Anstalten 31, 1-28.

Fischer W. 1922: Gephyreen der Arktischen Meere. (Gephyreans of the Arctic seas) Wissenschaftliche Meeresuntersuchungen Abteilung Helgoland 13, 229-246.

Fischer W. 1929: Die Sipunculiden, Priapuliden und Echiuren der Arktis. (Arctic Sipuncula, Priapulada and Echiura). In F. Römer \& F. Schaudinn (eds.): Fauna Arctica. Vol. 5. Pp. 451-490. Jena: Verlag von Gustav Fischer.

Gibbs P.E. 1975: Gametogenesis and spawning in a hermaphroditic population of Golfingia minuta (Sipuncula). Journal of the Marine Biological Association of the United Kingdom 55, 6982.

Gibbs P.E. 2001: Sipunculans. Key and notes for the identification of British species. Synopses of the British fauna (New Series) 12 . Dorchester: Linnean Society of London/Estuarine and Coastal Sciences Association.

Gray J.S. 2001: Antarctic marine benthic biodiversity in a world-wide latitudinal context. Polar Biology 24, 633-641.

Gulliksen B., Palerud R., Brattegard T. \& Sneli J. 1999: Distribution of marine benthic macro-organisms at Svalbard (including Bear Island) and Jan Mayen. Research Report for DN 1999-4. Trondheim: Directorate for Nature Management.

Hylleberg J. 1970: Fauna associated with the sipunculid Phascolion strombi (Montagu), especially the parasitic gastropod Menestho diaphana (Jeffryes). Ophelia 7, 257-276.

Kohn A.J. 1975: Predation on sipunculans. In M.E. Rice \& M. Todoroviæ (eds): Proceedings of the International Symposium on the Biology of the Sipuncula and Echiura, Kotor. Pp. 313-333. Belgrade: Nauèno Delo Press.

Loeng H. 1991. Features of the physical oceanographic conditions of the Barents Sea. In E. Sakshaug et al. (eds.): Proceedings of the Pro Mare Symposium on Polar Marine Ecology, Trondheim, Norway, 12-16 May 1990. Polar Research 10, 5-18.

Maxmen A.B., King B.F., Cutler E.B. \& Giribet G. 2003. Evolutionary relationships within the protostome phylum Sipuncula; a molecular analysis of ribosomal genes and histone H3 sequence data. Molecular Phylogenetics and Evolution 27, 489-503.

Murina G.V. 1975: The geographical distribution of marine worms of the phylum Sipuncula of the World Ocean. In M.E. Rice \& M. Todorović (eds.): Proceedings of the International Symposium on the Biology of the Sipuncula and Echiura. Vol. 1. Pp. 9-18. Belgrade: Nauèno Delo Press.

Murina G.V. 1977: Marine worms of the Arctic and Boreal waters of Europe. (Morskie chervi sipunkulidy arkticheskikh i borealnykh 
vod Evrazii.) Identification books of the USSR fauna 111. Leningrad: Akademii Nauk SSSR.

Murina G.V. 1984: Ecology of Sipuncula. Marine Ecology Progress Series 17, 1-7.

Murina G.V. \& Sørensen J. 2004: Marine worms of the phylum Sipuncula in Faroese waters. Fróoskaparrit 51, 280-291.

Ormond R.F.G., Gage J.D. \& Angel M.V. 1997: Marine biodiversity. Patterns and processes. Cambridge: Cambridge University Press.

Romero-Wetzel M.B. 1987: Sipunculans as inhabitants of very deep, narrow burrows in deep-sea sediments. Marine Biology 96, 87-91.

Saiz-Salinas J.I. 1995: Sipuncula of the southeastern Weddell Sea (Antarctica). Polar Biology 15, 307-317.

Saiz-Salinas J.I. \& Pagola-Carte S. 1999: Sipuncula of the Magellan area compared with adjacent regions of Antarctica. Scientia Marina 63, 227-232.

Saiz-Salinas J.I. \& Villafranca Urchegui L. 1990: Sipuncula from the Alboran Sea and Ibero-Morroccan Bay. Journal of Natural History 24, 1143-1 177.

Scheltema R.S. 1975: The frequency of long-distance larval dispersal and rate of gene-flow between widely separated populations of sipunculans. In M.E. Rice $\&$ M. Todorović (eds.): Proceedings of the International Symposium on the Biology of the Sipuncula and Echiura. Pp. 199-210. Belgrade: Nauèno Delo Press.

Scheltema R.S. \& Hall J.R. 1975: The dispersal of pelagosphaera larvae by ocean currents and the geographical distribution of sipunculans. In M.E. Rice $\&$ M. Todorović (eds): Proccedings of the International Symposium on the Biology of the Sipuncula and Echiura. Pp. 103-115, Belgrade: Nauèno Delo Press.

Scheltema R.S. \& Rice M.E. 1990: Passive dispersal of planktonic larvae and the biogeography of tropical sublittoral invertebrate species. In G. Colombo et al. (eds.): Marine eutrophication and population dynamics. Pp. 195-202. Fredenborg: Olsen and Olsen.

Schulze A., Cutler E.B. \& Giribet G. 2007. Phylogeny of sipunculan worms: a combined analysis of four gene regions and morphology. Molecular Phylogenetics and Evolution 42, 171192.

Sirenko B.I. 2001. List of species of free-living invertebrates of Eurasian Arctic seas and adjacent deep waters. Explorations of the fauna of the Seas 51, St Petersburg: Zoological Institute, Russian Academy of Sciences.

Staton J. \& Rice M.E. 1999. Genetic differentiation despite teleplanic larval dispersal: allozyme variation in sipunculans of the Apionsoma misakianum species complex. Bulletin of Marine Science 65, 467-480.
Stearley R.F. \& Ekdale A.A. 1989: Modern marine bioerosion by marcoinvertebrates from the northern Gulf of California. Palaois 4, 453-467.

Stevens G.C. 1989: The latitudinal gradient in geographical range: how so many species coexist in the tropics. The American Naturalist 33, 337-351.

Svendsen H., Beszczynska-Möller A., Hagen J.O., Lefauconnier B., Tverberg V., Gerland S., Orbæk J.B., Bischof K., Papucci C., Zajạczkowski M., Azzolini R., Bruland O., Wiencke C., Winther J.G. \& Dallmann W. 2002: The physical environment of Kongsfjorden-Krossfjorden, an Arctic fjord system in Svalbard. Polar Research 21, 133-166.

Théel H. 1905: Northern and Arctic invertebrates in the collection of the Swedish State Museum. I. Sipunculids. Kungliga Svenska Vetenskapsakademiens Handlingar 3, 1-30.

Wesenberg-Lund E. 1925: Gephyreer. Conspectus Faunae Groenlandicae. (Gephyreans. Conspectus of Greenland fauna.) Meddelelser om Grønland 23, 81-91.

Wesenberg-Lund E. 1930: Priapulida and Sipunculidae. Danish Ingolf Expedition 4, 1-44.

Wesenberg-Lund E. 1933: The collections of gephyreans in the Royal Museum of Natural History of Belgium. Bulletin de l'Institut Royal des Sciences Naturelles de Belgique 9, 1-15.

Wesenberg-Lund E. 1934: Gephyrans and annelids. The Scoresby Sound Committee's Second East Greenland Expedition in 1932 to King Christian 9th's Land. Meddelelser om Grønland 104, 1-38.

Wesenberg-Lund E. 1937a: The Zoology of East Greenland: gephyreans. Meddelelser om Gronland 121, 1-25.

Wesenberg-Lund E. 1937b: Gephyrea. The Zoology of Iceland 2, $1-17$.

Wesenberg-Lund E. 1938: The Godthaab Expedition 1928. Gephyrea. Meddelelser om Gronland 79, 1-29.

Wesenberg-Lund E. 1955: Sipunculidae. Reports of the Swedish Deep-Sea Expedition. Zoology 2, 199-201.

Wȩsławski J.M., Zajaczkowski M., Kwaśniewski S., Jezierski J. \& Moskal W. 1988: Seasonality in an Arctic fjord ecosystem: Hornsund, Spitsbergen. Polar Research 6, 185-189.

Włodarska-Kowalczuk M., Kendall M.A., Wȩsławski J.M., Klages M. \& Soltwedel T. 2004: Depth gradients of benthic standing stock and diversity on the continental margin at a high-latitude ice-free site (off Spitsbergen, $79^{\circ} \mathrm{N}$ ). Deep-Sea Research Part I 51, 1903-1914.

Włodarska-Kowalczuk M. \& Pearson T.H. 2004: Soft-bottom macrobenthic faunal associations and factors affecting species distribution in an Arctic glacial fjord (Kongsfjord, Spitsbergen). Polar Biology 27, 155-167. 


\section{Appendix. Simplified identification key to families, genera and species of Sipuncula from the Arctic region (Svalbard species are indicated in boldface).}

Key to families of class Sipunculidea:

1. Longitudinal muscles of body wall gathered into either separate or anastomosing bands (20-24)

- Longitudinal muscles of body wall in uniform continuous layer

2. A single nephridium present

- Two nephridia present

Key to Golfingiidae:

1. Four introvert retractor muscles present

- Two introvert retractor muscles present

Key to Golfingia species

1. Introvert hooks in rings

- Introvert hooks scattered, if present

2. Hooks present and scattered; central part of the trunk smooth, often transparent, both trunk ends dark and heavy papillated

- Hooks on introvert absent; small papillae present on the trunk

Key to Nephasoma species

1. Hooks absent

- Hooks scattered

- Hooks arranged in rings or otherwise

2. Scattered small hooks; body transparent to translucent, usually $<10 \mathrm{~mm}$ long

- Scattered small triangular hooks; body opaque, up to $40 \mathrm{~mm}$ long. From bathyal depths

3. Body skin smoothly glossy and transparent; introvert with a few short tentacular lobes

- Body skin translucent to opaque, with irregular longitudinal epidermal ridges on the introvert base and the anterior part of the trunk

4. Large hooks $(>50 \mu \mathrm{m})$ in a spiral arrangement, like a barber's pole

Key to Phascolionidae:

1. Epidermal holdfast papillae present

2. Epidermal holdfast papillae absent

Key to Phascolion species:

1. Ventral retractor much thinner then dorsal; holdfast papillae V-shaped with dark, hardened border

2. Ventral and dorsal retractors have equal width; large holdfast papillae without hardened borders

Key to Onchnesoma species:

1. Trunk covered with prominent backward directed protrusions; eight tentacles

2. Trunk flat without spherical protrusions or scales; tentacles absent

\author{
Sipunculus norvegicus \\ 2 \\ Phascolionidae \\ Golfingiidae \\ Golfingia \\ Nephasoma \\ Golfingia elongata \\ 2 \\ Golfingia vulgaris (Fig. 3)
}

Golfingia margaritacea (Fig. 4)

Nephasoma eremita (Fig. 5)

2

4

3

Nephasoma lilljeborgi (Fig. 6)

Nephasoma diaphanes diaphanes (Fig. 7)

Nephasoma diaphanes corrugatum

Nephasoma abyssorum

Phascolion

Onchnesoma

P. strombus (Fig. 8)

P. turberculosum

O. squamatum

O. steenstrupii 


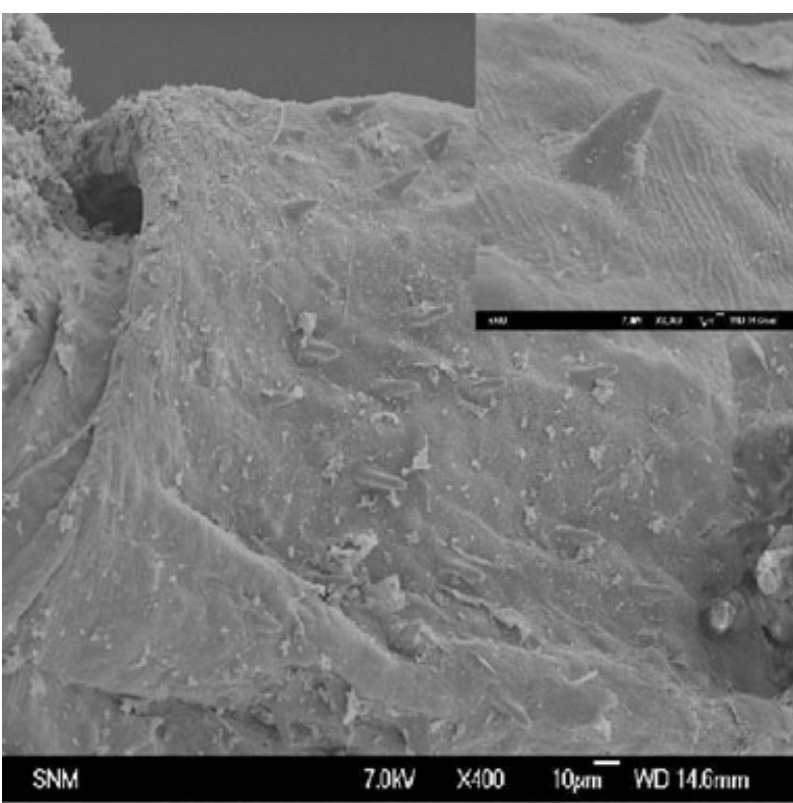

Figure 3 Scanning electron micrographs of the small hooks of Golfingia vulgaris. (Scanning electron microscope pictures were taken at the Zoological Museum of the University of Copenhagen.)

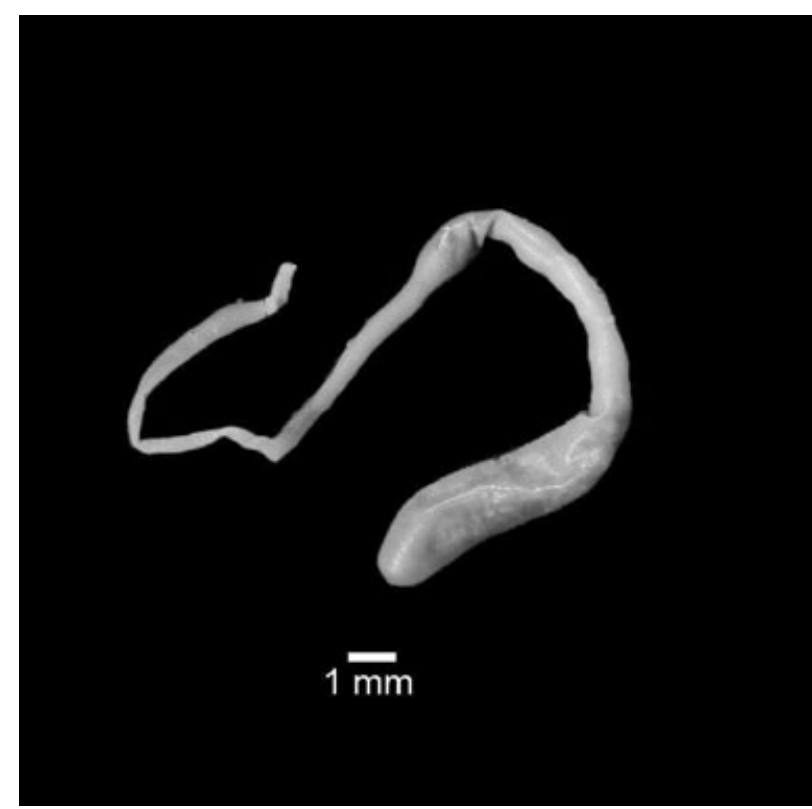

Figure 6 Nephasoma lilljeborgi.

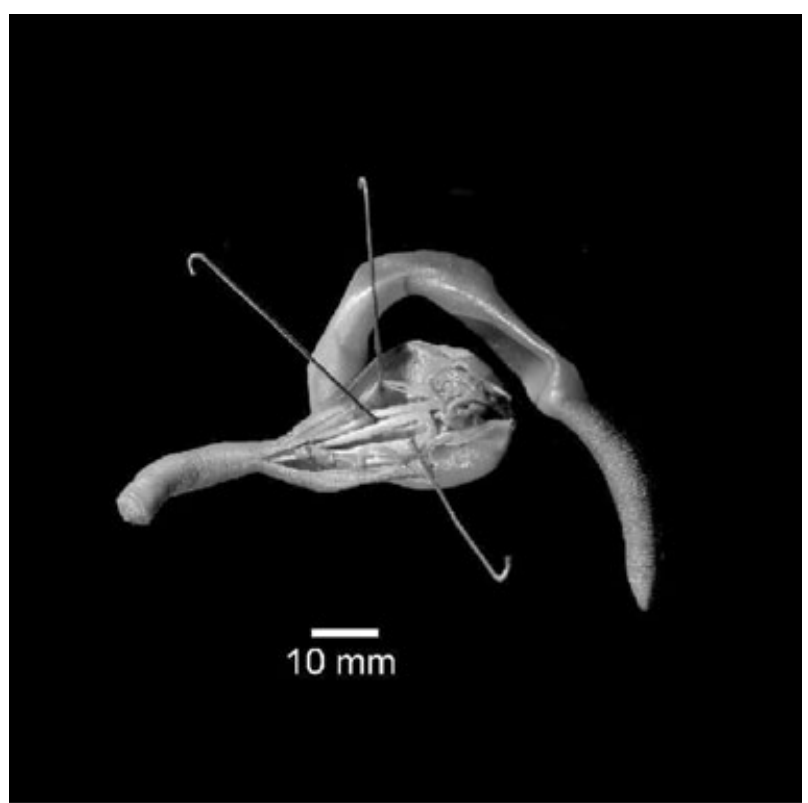

Figure 4 The interior organs of Golfingia margaritacea showing four introvert retractor muscles.

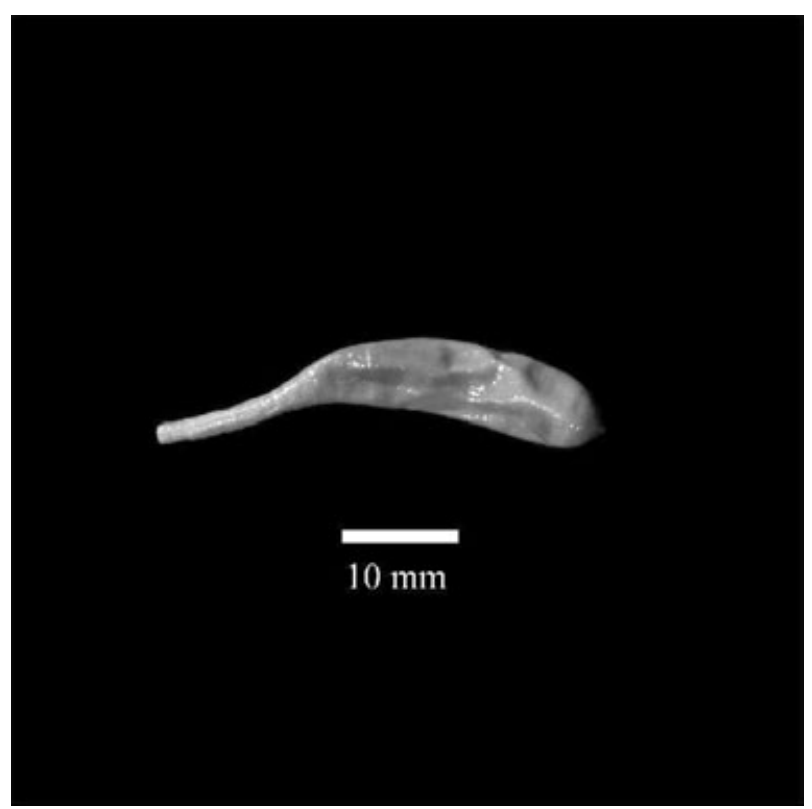

Figure 5 Golfingia eremita. 


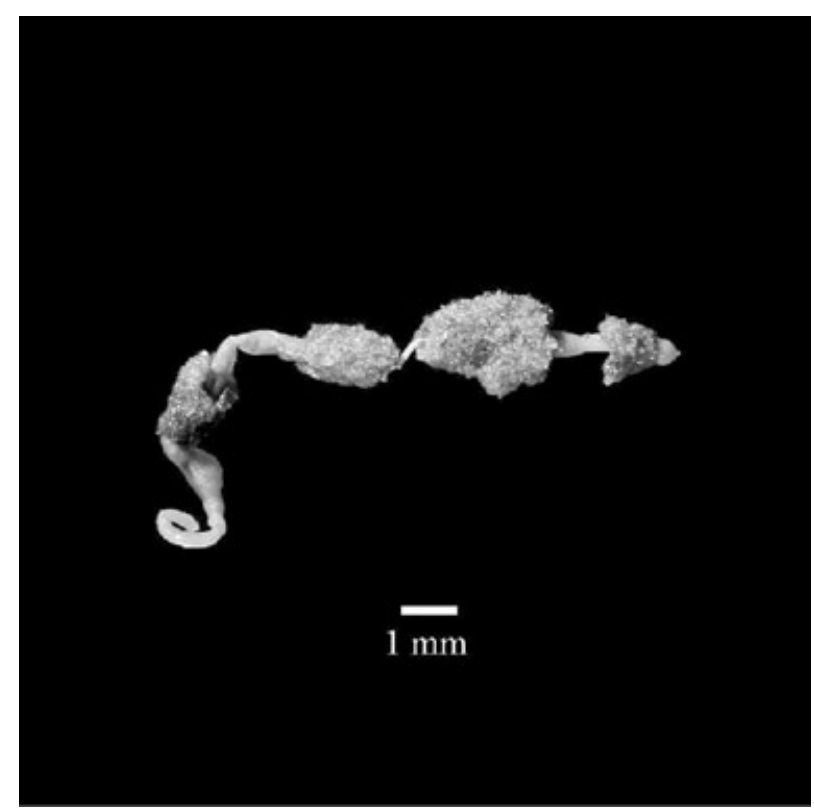

Figure 7 Nephasoma diaphanes diaphanes in foraminiferal tests.

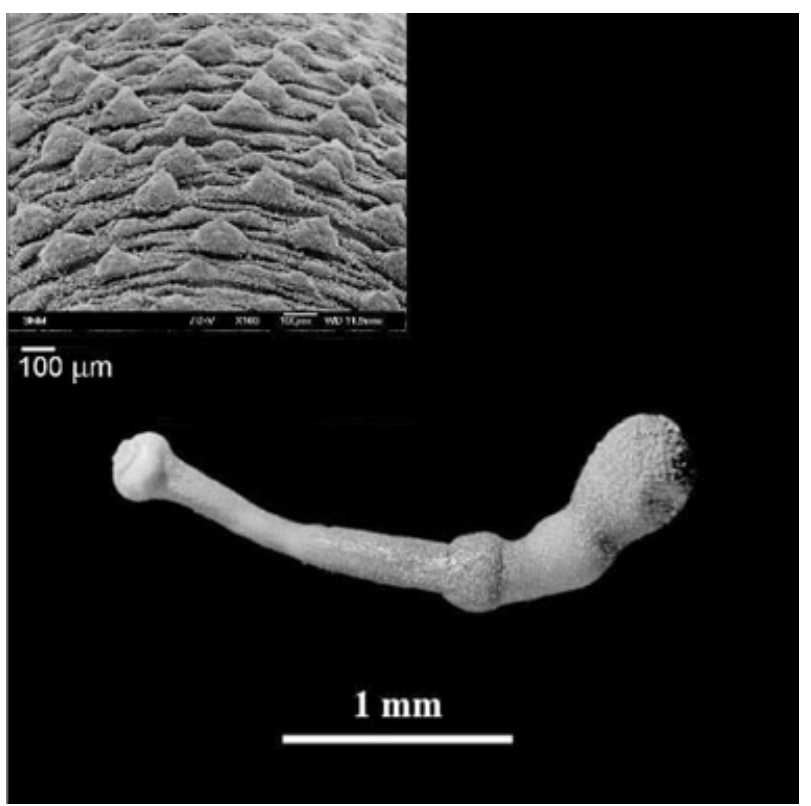

Figure 8 Phascolion strombus. Scanning electron micrographs of the holdfast papillae of $P$. strombus. 